\title{
The Role of social media marketing in improving marketing performance for smes during the covid-19 pandemic: a literature review
}

\author{
Vivi Herlina ${ }^{1^{*}}$, Syahmardi Yacob², Johannes ${ }^{3}$, Ade Octavia ${ }^{4}$ \\ 1,2,3,4 Doctoral Program in Economics, Faculty of Economics and Business, Universitas Jambi, \\ Indonesia \\ Corresponding author: viviherlina124@gmail.com
}

\begin{abstract}
The presence of social media affects the marketing strategies for all businesses. This study aimed to formulate a social media marketing model for SMEs during the Covid-19 pandemic. The study conducted a literature review that examined various studies in social media marketing customer engagement and marketing performance. The exogenous variables were entrepreneurial orientation and market orientation. This study provides a model for the social media marketing and customer engagement research model as the intervening variables and research questions development for further research.
\end{abstract}

Keywords: customer engagement; entrepreneurial orientation; market orientation; marketing performance; social media marketing

\section{INTRODUCTION}

SMEs are improving the national economy and as a solution for expanding employment opportunities. SMEs employment in Indonesia of 97.24\% (Jaswadi et al., 2015). Even when a recession hit Indonesia during the Covid-19 pandemic, SMEs could survive and contribute to state revenues from the tax sector (Febriyantoro \& Arisandi, 2018; Santoso, 2020).

Technological advances require all businesses to implement digital technology as a marketing tool (Salehi et al., 2012). Social media marketing as one of digital marketing is a form of consumer behavioraltering. Many SMEs do not know about digital marketing advantages (Purwana et al., 2017). According to Kalei (2020), SMEs' defiance in Kenya is cheap goods from China. Indonesia is also facing similar problems as a challenge for SMEs in Indonesia.

There are many benefits of using social media marketing. A business will transcend demographic boundaries to introduce products extensively (Salehi et al., 2012). Others demonstrate that digital marketing can create low-cost communication processes (Oklander \& Tetiana Oklander, 2017). Product brand awareness will be recognized quickly (Oktaviani \& Rustandi, 2018). Therefore, SMEs have to implement social media marketing to increase marketing performance.

Several scholars have done social media marketing research. Kaushik et al. (2020) stated that an online platform establishes a product brand easier to be recognized across the countries. Teece \& Leih (2016) explained that small businesses could adjust and increase their resources by utilizing information technology. Business agility is related to integrating products and services for a dynamic market. Stone \& Woodcock (2014) also said that interactive marketing evolves in the digital world. Particularly with the presence of smartphones, it is easy for consumers to get product information.

The Covid-19 pandemic is a global phenomenon that shifted business activities. Adopting social media as a business tool could affect SMEs ' sustainability (Patma et al., 2021). The Covid-19 pandemic compels consumers to spend less time in offline stores likewise shops and supermarkets. Therefore, in- 
store promotional products and purchasing will decline. Meanwhile, social media can raise procurement (Mason, Narcum, et al., 2021). Social media had a global reach to promote a product (Mason, Brown, et al., 2021). Therefore, usage of social media gains importance on the Covid-19 pandemic.

The distinguish to prior studies, the novelty of this research is to synthesize the influence of social media marketing during the Covid-19 pandemic. This study aims to develop a research model formulation of social media marketing on marketing performance for SMEs during the Covid-19 pandemic in Indonesia.

\section{LITERATURE REVIEW}

\section{Marketing Performance}

According to Gao (2010), marketing performance consists of three dimensions: effectiveness, efficiency, and adaptability to change. Effectiveness and efficiency were marketing activities carried out by the organization to obtain revenue, market growth, and market share. Meanwhile, Saeko et al. (2012) added that marketing performance is a business success factor combined with strategic marketing, market, and financial condition. The marketing performance consists of sales growth, market development, and market share. Ferdinand (2014) stated that good marketing performance focuses on sales value, growth, and market share. The three marketing definitions were strengthening each other. It can be concluded that marketing performance is influenced by three variables: market share, sales or revenue, and market development.

The purpose of marketing performance is to acquire a profit. The sales value could be in the form of money or the number of product units that have been sold. Sales growth indicates by sales increase compared to a specific time. The market share shows a product's contribution in market-dominating for similar products compared to competitors. Decent marketing performance is also indicated by sales growth (Widodo, 2008).

\section{Social Media Marketing}

Social media is an online platform for communication activities, discussions, social interactions, and online participation. Therefore, social media is also used as a platform to share content, promotion, review, products ranked, and services (Aryanto \& Wismantoro, 2020). While, Gunelius (2011) describes the purpose of social media marketing as increasing product, brand, even business awareness by using social websites, such as social networking, microblogging, and content sharing.

Many companies know that traditional marketing is inadequate to promote products and position a brand in this modern business era (Bruhn et al., 2012; Melović et al., 2020). Thus, social media marketing also affects marketing communication. Marketing communication was originally onedirectional become into multidirectional. According to Rangaswamy et al. (2020), digital marketing is dynamic and adaptive. Marketing strategies through digital marketing are done by changing the traditional marketing concepts because online products could influence marketing strategies development and decisions.

A posting in a video positively influences a product compared to text and images only. Furthermore, the endorsement system of a product can drive positive feedback to a product and a brand (Dhaoui \& Webster, 2020). Since the widespread utilization of smartphones, social media users is increased to change the consumer's perspective on a brand. Even a lot of consumers are bound by a brand, only by clicking the "Like" or "Share" button (Hewett et al., 2016). Yoon et al. (2018) and Goh et al. (2012) appended that positive comments on social media can positively affect the income of a business. Therefore, social media is a word-of-mouth tool that can be accessed easily. Moreover, on the Covid-19 pandemic, social media is essential to reach customers.

\section{Customer Engagement}

Customer engagement is an effort to build and improve a company's relationship with customers to maintain business performance (Brodie et al., 2013). Another elucidation of customer engagement is interactions between customers and companies of marketing activities (So et al., 2014). Furthermore, Hollebeek et al. (2014) stated that customer engagement is involvement between customers and companies through communication, experience, and online community. Moreover, Dessart et al. (2015) 
propound customer engagement as a form of marketing business binding consumers to maintain brand loyalty. In conclusion, customer engagement attempts to involve the customer with a company to create fidelity.

Marolt et al. (2020) studied the role of customer engagement in large-scale companies show that customer engagement affects marketing performance. Meanwhile, Mohammad (2020) analyzed the influence of customer empowerment and customer engagement on marketing performance. This study used loyalty as one of the marketing performance dimensions for marketing performance variables. This research found that customer engagement had a positive effect on marketing performance. Garg et al. (2020) examined customer engagement from the point of view of technology industry business performance in India. The results showed that business performance is also influenced by customer engagement.

\section{Entrepreneurial Orientation}

The entrepreneurial concept was described by Covin and Slevin (1991) as an integrated model that entrepreneurial behavior has linkages with business performance. T. Lee \& Chu (2011), Kumalaningrum (2012), and Lukiastuti (2012) stated that entrepreneurial orientation was the ability of a company to identify and also utilize opportunities. Meanwhile, Ahimbisibwe \& Abaho (2013) appended that a company with entrepreneurial orientation will become a risk-taker. In brief, entrepreneurial orientation is prominent in the dynamic business competition nowadays.

Each MSME needs to foster an entrepreneurial attitude to still exist in the competition in a competitive business. Because of, entrepreneurial orientation has a linkage to the business capability. Many studies found that entrepreneurial orientation affects both large and small business performance. Likewise, research by Pratono \& Mahmood (2015) examined the ability of MSME to survive in the middle of a turbulent environment. The finding of this research stated that entrepreneurial orientation affected MSME performance. Octavia et al. (2019) particularized about SME of halal food in Jambi Province. The finding showed a positive influence of entrepreneurial orientation and customer engagement on business performance. Moreover, Sa \& Chai (2020) obtained that entrepreneurial orientation significantly affected MSME performance in Malaysia's lodging business sector.

\section{Market Orientation}

In improving marketing performance, a company should have a market orientation. By having market orientation, a business will have the competence to recognize its customers to provide customer satisfaction. These things are reflected through market orientation (Jayaningrum \& Sanawiri, 2018). It was the same as Day (1994) showed a business with market orientation would have the proper ability to appertain with customers. Through market orientation, a business can get more vantage, rather than those that do not have it.

The market orientation on marketing performance research also got different results. Oduro \& Haylemariam (2019) examined market orientation in Ghana and Ethiopia's manufacturing industry. The CSR variable moderates the market orientation as an independent variable. The results demonstrate two things. First, market orientation could improve marketing performance. Second, market orientation also improves financial performance. Moreover, Sriayudha et al. (2019) examined the relationship between entrepreneurial orientation and market orientation SMEs business performance. This study indicated that both dependent variables affected the business performance.

Furthermore, Puspaningrum (2020) studied the effect of market orientation on marketing performance by using competitive advantages as a mediation variable. The analysis results found that market orientation positively influenced the performance of SME marketing. Likewise, Riswanto (2020) propounds that market orientation directly affects the marketing performance positively and through innovation as a mediation variable indirectly.

\section{DISCUSSION}

\section{The effect of entrepreneurial orientation on social media marketing}

Entrepreneurial orientation and innovation orientation positively affect using social media strategies. The study was conducted on 207 fashion brands in Taiwan and analyzed using SEM and FSQCA (Fuzzy-Set Comparative Analysis) using the Resource-Based View concept. This analysis 
found evidence that using social media as a marketing strategy can intensify both the company's success and competitiveness (Wu et al., 2020). In Faisal et al. (2018), entrepreneurship orientation was positive and significantly affected social media orientation. It shows that SMEs with a higher entrepreneurial orientation will have a higher social media orientation. The implication of this study suggested for SMEs to use social media to improve business performance.

Additionally, Eggers et al. (2017) outline the importance of social media in advancing SMEs. SMEs need to strengthen entrepreneurial resources. One of the ways that can be done is workers empowered to develop social networking skills. Thus, SMEs should take advantage of social media to improve business performance. It was obtained based on entrepreneurial orientation affected social media development positively for SMEs in several countries in Europe. This study also stated that responsive market orientation has no significant effect on using social media. Those previous studies show that entrepreneurial orientation positively affects social media marketing.

\section{The effect of social media marketing on marketing performance}

Winarti (2021) explains that social media provides many advantages in digital marketing. It includes the communication process that can be done reciprocally, information dissemination such as product promotion can be done quickly and cheaply, and customer identification processes will be easier (Rohm et al., 2013). These activities can be done cheaply (Gümüs \& Kütahyali, 2017). In social media marketing, Artaya \& Baktiono (2016) researched to find out whether marketing through social media could increase SME sales significantly. The independent variables used in this study were some social media platforms consisting of Facebook, Twitter, Instagram, and Youtube. The number of samples was 62 SMEs and multiple linear regression as an analysis method. This study obtained that all social media platforms significantly affected SMEs' sales value. Mason et al. (2021) demonstrated that on the Covid-19 pandemic, usage of social media as a business tool increased significantly.

Other studies conducted by Ritz et al. (2019) examined the application of digital marketing in small businesses by using the Do-It-Your (DIY) model and Technology Acceptance Model (TAM). This research indicates that small business owners must do technology utilization. Although, technology usage is not the only factor to succeed in a business. Meanwhile, Pranoto \& Lumbantobing's study (2021) analyzed the Technology Acceptance Model of social media marketing. This study involved 163 respondents of MSME owners in Jakarta. Data analysis using SEM-PLS. The study concluded that social media marketing positively and significantly affects MSMEs performance. Indeed, Aftab et al. (2021) examined SME performance in Pakistan using 400 respondents. Data analysis used a Two-Stage Structural Equation Model. This study obtained that social media marketing and product innovation affect SME performance positively and significantly. By the prior studies, it can be stated that social media marketing affects marketing performance.

\section{The effect of market orientation on customer engagement}

Kohli \& Jaworski (1990) stated that one of the goals of market orientation was the company's view to focus on consumers. Meanwhile, according to Dessart et al. (2015), Customer Engagement could be seen from a sense of interest or enthusiastic deportment of consumers on a product. Instead, the customers are willing to refer it to others. Many studies showed that market orientation has a linkage with customer engagement.

Mamun et al. (2018) studied the effect of entrepreneurial orientation and market orientation on consumer engagement and manufacturing SME's performance in Malaysia. The study was conducted on 360 SME manufacturing and analyzed by using SEM-PLS. This study stated that entrepreneurial orientation and market orientation had a positive effect on consumer engagement significantly. Alike, consumer engagement also affects SME performance significantly. The implication of this study explained the importance of managers or owners of SMEs to develop strategies that could involve consumers while improving performance. In addition, SMEs owners should maintain the relationship with consumers through dialogue or contrive sustainable relationships.

Furthermore, Ahmadi et al. (2019) investigated the relationship between entrepreneurial attitude and market orientation on customer engagement in Tehran. This research used 120 respondents to all managers and supervisors at the Mammut Industrial Group, and the data were analyzed with SEM using Lisrel. The results showed that market orientation and customer engagement had a significant relation. 
From the short review above, market orientation has a positive effect on customer engagement significantly.

\section{The effect of social media marketing on customer engagement}

Social media can build customer engagement with a company (Schultz \& Peltier, 2013). Using social media can create two-way communication between consumers and the company. Therefore, by optimizing social media, the company can trace customer needs. Thus, social media can establish relationships between companies and consumers through a community, and the process will develop customer loyalty (Joseph, 2011). Interesting content could encourage customer engagement through social media (Kilgour et al., 2015). Customer involvement through social media could be identified by the frequency of accessing websites, like, subscribing information, or following the latest content distributed (Ahmad et al., 2016), tweeting, or endorsing company products (Coker et al., 2015).

Facebook usage has a positive effect on customer engagement. Facebook users who tend to be involved with the Brands Pages will also contribute by commenting and sharing the page through a personal network (Tsai \& Men, 2013). Social network marketing has a significant effect on customer engagement. People who spend time with social media tend to be more involved with products, brands, and companies. Thus, a company attains customer engagement, so social media users will positively view products and brands (VanMeter et al., 2015). Toor et al. (2017) analyzed the influence of social network marketing on purchase intention mediated by customer engagement in 300 Pakistan social media users. The data analysis process used SEM. The summary of this study was stated that social network marketing influenced purchase intention significantly. Likewise, customer engagement as the mediator is also influenced by social network marketing. This research showed that social media usage evolves customer engagement and increases purchasing. Therefore, based on the prior study, social media marketing positively affects customer engagement.

\section{The effect of customer engagement on marketing performance}

Customer engagement has a positive and significant effect on marketing performance (Garg et al., 2020; Herdiany \& Yuliati, 2019; Onamusi \& Adenekan, 2020). Herdiany \& Yuliati (2017) stated that customer engagement had a positive and significant effect on repeated purchases on iPhone products. Meanwhile, Mohammad (2020) investigated the relationship between customer empowerment and customer engagement on marketing performance. The population of this study was college students in Northern Jordan. There were 1320 questionnaires were distributed, but 895 questionnaires were returned. For marketing performance variables, this study used customer loyalty as one of the marketing performance dimensions. The analysis found that customer engagement had a positive effect on marketing performance.

Withal Marolt et al. (2020) investigated the role of customer engagement for SMEs in the Slovenian Republic. The number of data was analyzed by 119 from SME owners and managers. Data analysis was using SEM. The results showed that customer engagement built by the company affects marketing performance. Meanwhile, Garg et al. (2020) observed customer engagement from the standpoints of Information Technology and retail industry business performance in India. Data were processed using SEM from 281 questionnaires. The finding stated that business performance is influenced by customer engagement. Onamusi \& Adenekan (2020) examine customer engagement and the relation to marketing performance on baby care products in Nigeria. This study used market share as one of the marketing performance indicators, and the results explained that customer engagement has a significant effect on market share.

The constructs are used in this study consists of entrepreneurial orientation and market orientation as the exogenous variable. Meanwhile, the endogenous variable is marketing performance, and the mediation variables are social media marketing and customer engagement. The framework of this study is shown in Figure 1. 


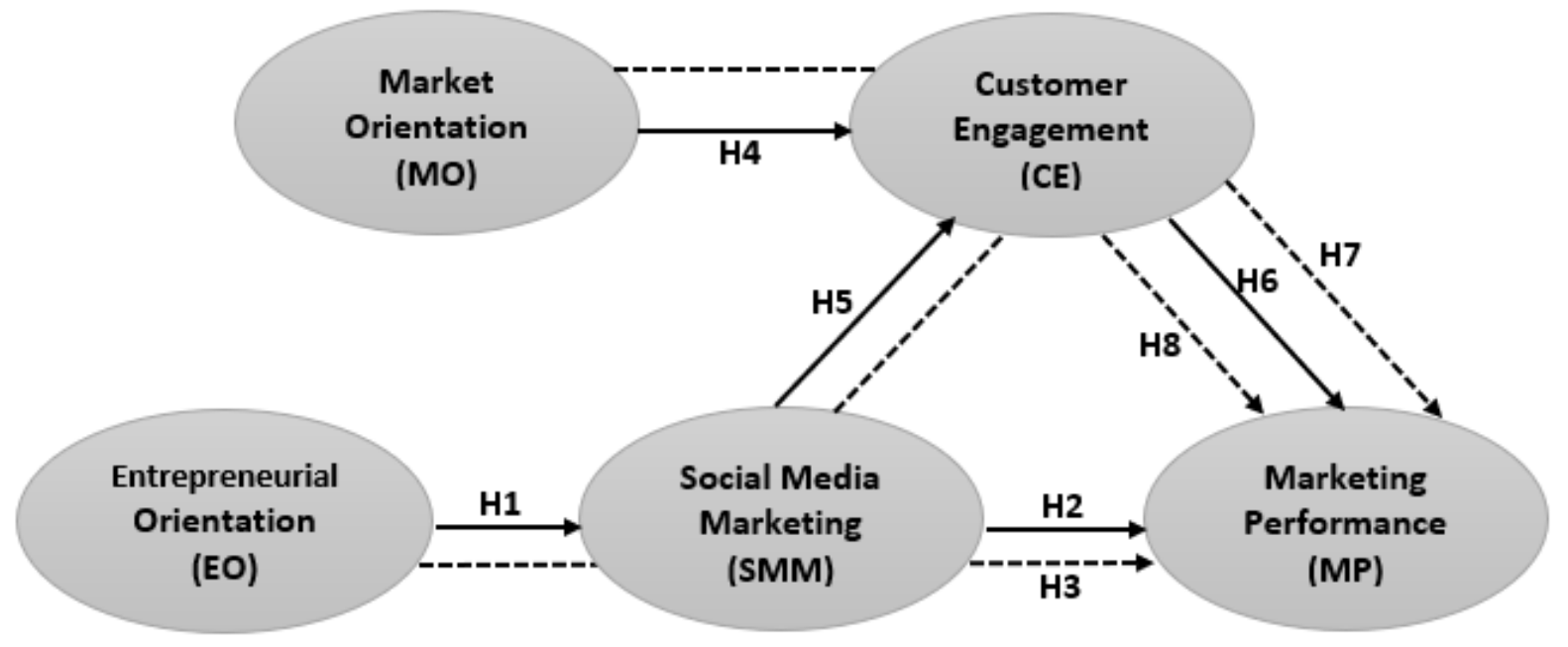

Figure 1. Social Media Marketing framework for SMEs in pandemic season

Based on the above explanation, the hypothesis proposed is:

$\mathbf{H}_{\mathbf{1}}$ : Entrepreneurial orientation will positively impact social media marketing

$\mathbf{H}_{2}$ : Social media marketing will positively impact marketing performance

$\mathbf{H}_{3}$ : Entrepreneurial orientation will positively impact marketing performance through social media marketing

$\mathbf{H}_{4}$ : Market orientation will positively impact customer engagement

$\mathbf{H}_{5}$ : Social media marketing will positively impact customer engagement

$\mathbf{H}_{6}$ : Customer engagement will positively impact marketing performance

$\mathbf{H}_{7}$ : Market orientation will positively impact marketing performance through customer engagement

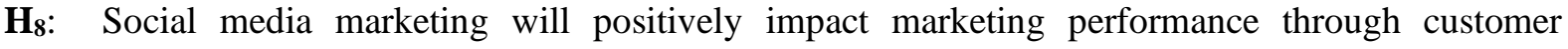
engagement

\section{CONCLUSION}

Social media marketing has a role in improving SMEs' marketing performance. This study has formulated a research model by implementing two exogenous variables: entrepreneurial orientation and market orientation, and the intervening variables were social media marketing and customer engagement. There are eight hypotheses constructed in this study. During the Covid-19 pandemic, social media marketing is beneficial for SMEs to market a product. Using social media marketing could extend a more broad market area. Likewise, social media can promote SME products around the SME environment and trans-border.

Furthermore, social media marketing does not promote products statically. Even more, social media would connect both buyers and sellers to engage customers. Indeed, customer engagement will raise consumers to make sustainable purchasing and recommend it to others.

\section{REFERENCES}

Aftab, M., Aziz, A., Abdullah, B., Rehman, A. U., Sarwar, H., Majid, B., \& Nawal, A. (2021). Modeling Entrepreneurial Marketing, Social Media Marketing, Product Innovation, and SME's Performance. Psychology and Education, 58(5), 1615-1629. http://psychologyandeducation.net/pae/index.php/pae/article/view/5557

Ahimbisibwe, G., \& Abaho, E. (2013). Export Entrepreneurial Orientation and Export Performance of SMEs in Uganda. Global Advanced Research Journal of Management and Business Studies, 2(1), 56-62. http://garj.org/full-articles/export-entrepreneurial-orientation-and-export-performance-ofsmes-in-uganda.pdf

Ahmad, N. S., Musa, R., \& Harun, M. H. M. (2016). The Impact of Social Media Content Marketing 
(SMCM) towards Brand Health. In W. et al. Edura (Ed.), Procedia Economics and Finance (Vol. 37, Issue 16, pp. 331-336). Elsevier B.V. https://doi.org/10.1016/s2212-5671(16)30133-2

Ahmadi, F., Monavariyan, A., \& Manesh, M. R. Z. (2019). Relationship Investigation between Entrepreneurial Attitude and Market Orientation, Considering Consumers' Engagement Mediation. International Journal of Business Management, 4(4), 13-24. https://sciarena.com/en/article/relationship-investigation-between-entrepreneurial-attitude-andmarket-orientation-considering-consumers-engagement-mediation

Artaya, I. P., \& Baktiono, R. A. (2016). Memilih Media Sosial Yang Efektif Sebagai Sarana Marketing Online Bagi Pelaku UKM di Kabupaten Sidoarjo. Jurnal Spirit Pro Patria, 2(2), 8-21. https://doi.org/10.29138/spirit pro patria.v2i2.516

Aryanto, V. D. W., \& Wismantoro, Y. (2020). Marketing Digital Solusi Bisnis Masa Kini dan Masa Depan (R. de L. Novita (ed.)). PT Kanisius.

Brodie, R. J., Ilic, A., Juric, B., \& Hollebeek, L. (2013). Consumer engagement in a virtual brand community: An exploratory analysis. Journal of Business Research, 66(1), 105-114. https://doi.org/10.1016/j.jbusres.2011.07.029

Bruhn, M., Schoenmueller, V., \& Schäfer, D. B. (2012). Are social media replacing traditional media in terms of brand equity creation? Management Research Review, 35(9), 770-790. https://doi.org/10.1108/01409171211255948

Coker, K. K., Smith, D. S., \& Altobello, S. A. (2015). Buzzing with disclosure of social shopping rewards. Journal of Research in Interactive Marketing, 9(3), 170-189. https://doi.org/10.1108/JRIM-06-2014-0030

Day, G. S. (1994). The Capabilities of Market-Driven Organizations. Journal of Marketing, 58(4), $37-$ 52. https://doi.org/10.1177/002224299405800404

Dessart, L., Veloutsou, C., \& Morgan-Thomas, A. (2015). Consumer engagement in online brand communities: a social media perspective. Journal of Product \& Brand Management, 24(1), 28 42. https://doi.org/10.1108/JPBM-06-2014-0635

Dhaoui, C., \& Webster, C. M. (2020). Brand and consumer engagement behaviors on Facebook brand pages: Let' s have a (positive) conversation. International Journal of Research in Marketing. https://doi.org/10.1016/j.ijresmar.2020.06.005

Eggers, F., Hatak, I., Kraus, S., \& Niemand, T. (2017). Technologies that support marketing and market development in SMEs - Evidence from social networks. Journal of Small Business Management, 55(22), 270-302. https://doi.org/10.1111/jsbm.12313

Faisal, A., Hermawan, A., \& Arafah, W. (2018). The Influence of Strategic Orientation on Firm Performance Mediated by Social Media Orientation at MSMEs. International Journal of Science and Engineering Invention, 4(08), 22-31. https://doi.org/10.23958/ijsei/vol04-i08/03

Febriyantoro, M. T., \& Arisandi, D. (2018). Pemanfaatan Digital Marketing Bagi Usaha Mikro, Kecil dan Menengah Pada Era Masyarakat Ekonomi ASEAN. Jurnal Manajemen Dewantara, 1(2), 6176. http://ejournal.stiedewantara.ac.id/index.php/JMD/issue/view/32

Ferdinand, A. (2014). Metode Penelitian Manajemen (5th ed.). Badan Penerbit Universitas Diponegoro.

Gao, Y. (2010). Measuring Marketing Performance: A Review and A Framework. The Marketing Review, 10(1), 25-40. https://doi.org/10.1362/146934710X488924

Garg, P., Gupta, B., Dzever, S., Sivarajah, U., \& Kumar, V. (2020). Examining the Relationship between Social Media Analytics Practices and Business Performance in the Indian Retail and IT Industries: The Mediation Role of Customer Engagement. International Journal of Information Management, 52, 102069. https://doi.org/10.1016/j.ijinfomgt.2020.102069

Goh, K. Y., Heng, C. S., \& Lin, Z. (2012). Social Media Brand Community and Consumer Behavior: Quantifying the Relative Impact of User- and Marketer-Generated Content. SSRN Electronic Journal, October. https://doi.org/10.2139/ssrn.2048614

Gümüs, N., \& Kütahyali, D. N. (2017). Perceptions of Social Media by Small and Medium Enterprises (SMEs) in Turkey. International Journal of Business and Information, 12(2), 123-148. https://doi.org/10.6702/ijbi.2017.12.2.2

Gunelius, S. (2011). 30-Minutes Social Media Marketing. McGraw Hill.

Herdiany, M., \& Yuliati, A. L. (2019). Pengaruh Brand Performance Terhadap Repeat Purchase dengan Competitive Advantage dan Customer Engagement Sebagai Variabel Intervening pada Apple iPhone. Jurnal Ilmiah MEA (Manajemen, Ekonomi, \& Akuntansi) 1,2Universitas, 3(3), 101-110. 
https://doi.org/10.31955/mea.vol4.iss1.pp101-110

Hewett, K., Rand, W., Rust, R. T., \& van Heerde, H. J. (2016). Brand Buzz in the Echoverse. Journal of Marketing, 80(3), 1-24. https://doi.org/10.1509/jm.15.0033

Hollebeek, L. D., Glynn, M. S., \& Brodie, R. J. (2014). Consumer brand engagement in social media: Conceptualization, scale development and validation. Journal of Interactive Marketing, 28(2), 149-165. https://doi.org/10.1016/j.intmar.2013.12.002

Jaswadi, Iqbal, M., \& Sumiadji. (2015). SME Governance in Indonesia - A Survey and Insight from Private Companies. Procedia Economics and Finance, 31(15), 387-398. https://doi.org/10.1016/s2212-5671(15)01214-9

Jayaningrum, E., \& Sanawiri, B. (2018). Pengaruh Orientasi Pasar, Inovasi, Orientasi Kewirausahaan Terhadap Keunggulan Bersaing dan Kinerja Pemasaran. Jurnal Administrasi Bisnis (JAB)|, 54(1), 149-158. http://administrasibisnis.studentjournal.ub.ac.id/index.php/jab/article/view/2227

Jeffrey G. Covin, D. P. S. (1991). A Conceptual Model of Entrepreneurship as Firm Behavior. $\begin{array}{lllll}\text { Entrepreneurship Theory } \quad \text { and } & \text { Practice, }\end{array}$ https://doi.org/10.1177/104225879101600102

Joseph, T. (2011). APPS The Spirit of Digital Marketing 3.0. Elex Media Komputindo.

Kalei, A. M. W. (2020). Digital Marketing Strategies and Marketing Performance of Top 100 Small and Medium Enterprises (SMEs) in Kenya. International Journal of Research in Management \& Business Studies, 7(3), 26-31. http://ijrmbs.com/vol7issue3/anne.pdf

Kaushik, V., Kumar, A., Gupta, H., \& Dixit, G. (2020). A hybrid decision model for supplier selection in Online Fashion Retail (OFR). International Journal of Logistics Research and Applications, O(0), 1-25. https://doi.org/10.1080/13675567.2020.1791810

Kilgour, M., Sasser, S. L., \& Larke, R. (2015). The social media transformation process: curating content into strategy. Corporate Communications: An International Journal, 20(3), 326-343. https://doi.org/10.1108/CCIJ-07-2014-0046

Kohli, A. K., \& Jaworski, B. J. (1990). Market Orientation: The Construct, Research Propositions, and Managerial Implications. Journal of Marketing, 54(2), 1-18. https://doi.org/10.1177/002224299005400201

Kumalaningrum, M. P. (2012). Lingkungan Bisnis, Orientasi Kewirausahaan, Orientasi Pasar, Dan Kinerja Usaha Mikro, Kecil Dan Menengah. Jurnal Riset Manajemen Dan Bisnis, 7(1), 45. https://doi.org/10.21460/jrmb.2012.71.83

Lee, T., \& Chu, W. (2011). Entrepreneurial Orientation and Competitive Advantage: The Mediation of Resource Value and Rareness. African Journal of Business Management, 5(33), 12797-12809. https://doi.org/10.5897/AJBM11.1179

Lukiastuti, F. (2012). Pengaruh Orientasi Wirausaha dan Kapabilitas Jejaring Usaha Terhadap Peningkatan Kinerja UKM dengan Komitmen Perilaku (Studi Empiris pada Sentra UKM Batik di Sragen, Jawa Tengah). Jurnal Organisasi Dan Manajemen, 8(2), 155-175.

Mamun, A. Al, Mohiuddin, M., Fazal, S. A., \& Ahmad, G. Bin. (2018). Effect of entrepreneurial and market orientation on consumer engagement and performance of manufacturing SMEs. Management Research Review, 41(1), 133-147. https://doi.org/10.1108/MRR-04-2017-0102

Marolt, M., Zimmermann, H. D., \& Pucihar, A. (2020). Enhancing marketing performance through enterprise-initiated customer engagement. Sustainability (Switzerland), 12(9), 1-16. https://doi.org/10.3390/su12093931

Mason, A. N., Brown, M., Mason, K., \& Narcum, J. (2021). Pandemic effects on social media marketing behaviors in India. Cogent Business and Management, 8(1), 1-14. https://doi.org/10.1080/23311975.2021.1943243

Mason, A. N., Narcum, J., \& Mason, K. (2021). Social media marketing gains importance after Covid19. Cogent Business and Management, 8(1). https://doi.org/10.1080/23311975.2020.1870797

Melović, B., Jocović, M., Dabić, M., Vulić, T. B., \& Dudic, B. (2020). The impact of digital transformation and digital marketing on the brand promotion, positioning and electronic business in Montenegro. Technology in Society, 63. https://doi.org/10.1016/j.techsoc.2020.101425

Mohammad, A. A. (2020). The effect of customer empowerment and customer engagement on marketing performance: The mediating effect of brand community membership. Business: Theory and Practice, 21(1), 30-38. https://doi.org/10.3846/btp.2020.11617

Octavia, A., Zulfanetti, Z., Amir, A., Sriayudha, Y., \& Dean Amri, A. (2019). Entrepreneurial 
Orientation and Consumer Engagement: the Impact of Business Performance on Small and Medium Entreprises of Halal Food. Malaysian Management Journal, 23(December), 87-97. https://doi.org/10.32890/mmj.23.2019.9686

Oduro, S., \& Haylemariam, L. G. (2019). Market orientation, CSR and financial and marketing performance in manufacturing firms in Ghana and Ethiopia. Sustainability Accounting, Management and Policy Journal, 10(3), 398-426. https://doi.org/10.1108/SAMPJ-11-2018-0309

Oklander, M., \& Tetiana Oklander. (2017). Segmentation and Communication in Digital Marketing. Marketing and Management of Innovations, 3, 69-78. https://doi.org/10.21272/mmi.2017.3-07

Oktaviani, F., \& Rustandi, D. (2018). Implementasi Digital Marketing dalam Membangun Brand Awareness. PRofesi Humas: Jurnal Ilmiah Ilmu Hubungan Masyarakat, 3(1), 1-20. https://doi.org/10.24198/prh.v3i1.15878

Onamusi, A. B., \& Adenekan, T. E. (2020). Customer Engagement Capability and Market Share: A PLS-SEM Analysis. IAR Journal of Entrepreneurship, Innovation \& Design Thinking, 1(1), 3948. https://doi.org/10.47310/iajeidt2020.v01i01.006

Patma, T. S., Wardana, L. W., Wibowo, A., Narmaditya, B. S., \& Akbarina, F. (2021). The impact of social media marketing for Indonesian SMEs sustainability: Lesson from Covid-19 pandemic. Cogent Business and Management, 8(1). https://doi.org/10.1080/23311975.2021.1953679

Pranoto, A. H., \& Lumbantobing, P. (2021). The Acceptance Technology Model for Adoption of Social Media Marketing in Jabodetabek. The Winners, 22(1), 75-88. https://doi.org/10.21512/tw.v22i1.7073

Pratono, A. H., \& Mahmood, R. (2015). Entrepreneurial orientation and firm performance: How can micro, small and medium-sized enterprises survive environmental turbulence? Pacific Science Review B: Humanities and Social Sciences, 1(2), 85-91. https://doi.org/10.1016/j.psrb.2016.05.003

Purwana, D., Rahmi, R., \& Aditya, S. (2017). Pemanfaatan Digital Marketing Bagi Usaha Mikro, Kecil, Dan Menengah (UMKM) Di Kelurahan Malaka Sari, Duren Sawit. Jurnal Pemberdayaan Masyarakat Madani (JPMM), 1(1), 1-17. https://doi.org/10.21009/jpmm.001.1.01

Puspaningrum, A. (2020). Market Orientation, Competitive Advantage and Marketing Performance of Small Medium Enterprises (SMEs). Journal of Economics, Business, \& Accountancy Ventura, 23(1), 19. https://doi.org/10.14414/jebav.v23i1.1847

Rangaswamy, A., Moch, N., Felten, C., van Bruggen, G., Wieringa, J. E., \& Wirtz, J. (2020). The Role of Marketing in Digital Business Platforms. Journal of Interactive Marketing, 51, 72-90. https://doi.org/10.1016/j.intmar.2020.04.006

Riswanto, A., Rasto, Hendrayati, H., Saparudin, M., Abidin, A. Z., \& Eka, A. P. B. (2020). The role of innovativeness-based market orientation on marketing performance of small and medium-sized enterprises in a developing country. Management Science Letters, 10(9), 1947-1952. https://doi.org/10.5267/j.msl.2020.2.019

Ritz, W., Wolf, M., \& McQuitty, S. (2019). Digital Marketing Adoption and Success for Small Businesses: The Application of the Do-It-Yourself and Technology Acceptance Models. Journal of Research in Interactive Marketing, 13(2), 179-203. https://doi.org/10.1108/JRIM-04-20180062

Rohm, A., Kaltcheva, V. D., \& Milne, G. R. (2013). A mixed-method approach to examining brandconsumer interactions driven by social media. Journal of Research in Interactive Marketing, 7(4), 295-311. https://doi.org/10.1108/JRIM-01-2013-0009

Sa, M. L. L., \& Chai, Y. K. (2020). Managerial orientations and business performance in small and medium tourism accommodation businesses (SMTABs): A resource advantage-knowledge creation approach. International Journal of Entrepreneurship and Innovation, 21(1), 17-37. https://doi.org/10.1177/1465750318809517

Saeko, A. N., Chuntarung, P. T. (2012). The Impact of Integrated Marketing Strategy on Mareting Performance: An Empirical Evidence From Exporting Business in Thailand. International Journal of Business Strategy, 12(4).

Salehi, M., Mirzaei, H., Aghaei, M., \& Abyari, M. (2012). Dissimilarity of E-Marketing VS Traditional Marketing. International Journal of Business and Social Sciences, 2(1), 510-515. https://hrmars.com/papers/detail/IJARBSS/8716/Dissimilarity-of-E-marketing-VS-traditionalmarketing 
Santoso, R. (2020). Review of Digital Marketing \& Business Sustainability of E-Commerce During Pandemic Covid19 In Indonesia. Jurnal Ilmu Ekonomi Terapan, 5(2), 36-48. https://doi.org/10.20473/jiet.v5i2.23614

Schultz, D. E., \& Peltier, J. J. (2013). Social media's slippery slope: challenges, opportunities and future research directions. Journal of Research in Interactive Marketing, 7(2), 86-99. https://doi.org/10.1108/JRIM-12-2012-0054

So, K. K. F., King, C., Sparks, B. A., \& Wang, Y. (2014). The Role of Customer Engagement in Building Consumer Loyalty to Tourism Brands. Journal of Travel Research, 55(1), 64-78. https://doi.org/10.1177/0047287514541008

Sriayudha, Y., Octavia, A., \& Indrawijaya, S. (2019). Entrepreneurial Orientation and Market Orientation in Business Performance of SMEs: An Exploration of the Impact on E-Commerce Adoption. Advances in Economics, Business and Management Research, 145, 158-163. https://doi.org/10.18488/journal.aefr.2020.105.516.525

Stone, M. D., \& Woodcock, N. D. (2014). Interactive, direct and digital marketing A future that depends on better use of business intelligence. Journal of Research in Interactive Marketing, 8(1), 4-17. https://doi.org/10.1108/JRIM-07-2013-0046

Teece, D., \& Leih, S. (2016). Uncertainty, Innovation, and Dynamic Capabilities: An Introduction. California Management Review, 58(4), 5-12. https://doi.org/10.1525/cmr.2016.58.4.5

Toor, A., Husnain, M., \& Hussain, T. (2017). The impact of social network marketing on consumer purchase intention in Pakistan: Consumer engagement as a mediator. Asian Journal of Business and Accounting, 10(1), 167-199.

Tsai, W.-H. S., \& Men, L. R. (2013). Motivations and Antecedents of Consumer Engagement With Brand Pages on Social Networking Sites. Journal of Interactive Advertising, 13(2), 76-87. https://doi.org/10.1080/15252019.2013.826549

VanMeter, R. A., Grisaffe, D. B., \& Chonko, L. B. (2015). Of "Likes" and "Pins": The Effects of Consumers' Attachment to Social Media. Journal of Interactive Marketing, 32, 70-88. https://doi.org/10.1016/j.intmar.2015.09.001

Widodo. (2008). Meningkatkan Kinerja Pemasaran Dengan Kreativitas Strategi. Integritas - Jurnal Manajemen Bisnis, 1(2), 151-175.

Wijaya, N. (2017). Pengaruh Brand Performance Terhadap Repeat Purchase Dengan Competitive Advantage dan Customer Engagement Sebagai Variabel Intervening Pada Pengguna Sepeda Motor Honda di Surabaya. Jurnal Strategi Pemasaran, 4(2). http://publication.petra.ac.id/index.php/manajemen-pemasaran/article/view/5662

Winarti, C. (2021). Pemanfaatan Sosial Media oleh UMKM Dalam Memasarkan Produk di Masa Pandemi Covid-19. Prosiding Seminar Nasional Bisnis Seri Ke-4, 195-206. https://pascasarjanafe.untan.ac.id/wp-content/uploads/2021/01/19.pdf

Wu, C. W., Guaita Martínez, J. M., \& Martín Martín, J. M. (2020). An analysis of social media marketing strategy and performance in the context of fashion brands: The case of Taiwan. Psychology and Marketing, 37(9), 1185-1193. https://doi.org/10.1002/mar.21350

Yoon, G., Li, C., Ji, Y. (Grace), North, M., Hong, C., \& Liu, J. (2018). Attracting Comments: Digital Engagement Metrics on Facebook and Financial Performance. Journal of Advertising, 47(1), 2437. https://doi.org/10.1080/00913367.2017.1405753 